\title{
Penerapan Algoritma Genetika Pada Penentuan Lintasan Terpendek Jalur Bus Rapid Transit Makassar
}

\author{
Karels, Rheeza Effrains ${ }^{1)}$, Jusmawati ${ }^{2}$, Nurdin ${ }^{3)}$
}

\begin{abstract}
Bus Rapid Transit is a bus system that is fast, convenient, safe and on time from infrastructure, vehicles, and schedules. As a graph problem, BRT representation in a graph is done by assuming the bus stop as a vertices and the distance between bus stops is an edge. The problem examined in this paper is to find out the path that passes through all the bus stops with the smallest total distance, where the trip starts and ends at the same point, and all bus stops are crossed exactly once. The method used is the Genetic Algorithm, which works using objective and fitness functions, and combines selection, crossover and mutation operators to find the best solution. Using the roulette wheel, OX crossover method and a 0.07 of the probability of mutation, the distance of traverse from and to the departure point after passing all bus stops is $19.66 \mathrm{~km}$ or 12.22 miles.
\end{abstract}

Keywords: BRT (Bus Rapid Transit), Genetic Algorithm, Roulette Wheel Method

\begin{abstract}
Abstrak
Bus Rapid Transit atau disingkat BRT adalah sebuah sistem bus yang cepat, nyaman, aman dan tepat waktu dari infrastruktur, kendaraan dan jadwal. Sebagai permasalahan graf, representasi BRT sebagai graf dilakukan dengan menganggap halte sebagai titik dan jarak antar halte merupakan sisi. Permasalahan yang dikaji dalam tulisan ini bertujuan menemukan jalur yang melewati semua halte dengan total jarak paling kecil, dimana perjalanan berawal dan berakhir pada titik yang sama, dan semua halte dilewati tepat sekali. Metode yang digunakan adalah Algoritma Genetika, yang bekerja menggunakan fungsi obyektif dan nilai fitness, serta mengombinasikan antara operator seleksi, crossover dan mutasi untuk menemukan solusi terbaik. Dengan menggunakan metode seleksi roulette wheel, crossover OX dan peluang mutasi 0,07 diperoleh jarak tempuh dari sejak berangkat sampai kembali ke titik keberangkatan setelah melewati semua halte tepat sekali adalah 19,66 km atau 12,22 mil.
\end{abstract}

Kata Kunci : BRT (Bus Rapid Transit), Algoritma Genetika, metode roulette wheel.

\section{Pendahuluan}

Dalam kehidupan sehari - hari masalah transportasi di kota - kota besar sering menjadi kendala bagi pemerintah setempat dikarenakan jumlah kendaraan tiap tahunnya semakin bertambah, tidak terkecuali di kota Makassar. Hal ini mendorong pemerintah menciptakan sistem transportasi baru yang dikenal dengan nama BRT ( Bus Rapid Transit ). BRT diluncurkan oleh pemerintah dengan tujuan agar masyarakat memperoleh akses ke tempat sarana umum yang nyaman, murah, dan mempunyai fasilitas yang lengkap serta mengurangi kepadatan lalulintas yang disebabkan oleh kendaraan pribadi di Makassar yang kian hari semakin padat.

*Jurusan Matematika, Fakultas Matematika dan Ilmu Pengetahuan Alam, Universitas Hasanuddin

Email: karelsrheezaeffrains@gmail.com ${ }^{1)}$; jusmawati@gmail.com ${ }^{2)}$; nurdin1701@unhas.ac.id 
Salah satu hal yang menjadi pertimbangan dalam membangun BRT adalah menentukan jalur terpendek dari halte ke halte sehingga waktu tempuh maupun biaya operasional menjadi lebih efisien. Penentuan jalur terpendek merupakan salah satu kajian graf yang berkaitan dengan permasalahan Traveling Salesman Problem (TSP). Prinsip dari TSP adalah menemukan jalur (tour) yang paling pendek serta urutan kota-kota yang harus dilalui oleh salesman, sehingga diperoleh waktu tempuh/biaya/jarak paling minimum sampai setiap kota dikunjungi tepat satu kali.

Traveling Saleseman Problem merupakan permasalahan optimisasi, dan salah satu metode yang tepat digunakan untuk permasalahan tersebut adalah Algoritma Geentika. Algoritma Genetika tidak membtuhkan syarat dan asumsi tertentu, tetapi hanya menggunakan fungsi obyektif dan dapat menemukan alternative solusi terbaik untuk permasalahan yang tidak mempunyai solusi sekalipun.

\section{Beberapa Konsep Dasar dan Permasalahan Graf}

Permasalahan yang sering dijumpai di dunia nyata dapat diselesaikan melalui formulasi matematis, dan salah satu di antaranya adalah dengan melalui graf.

Graf merupakan struktur diskrit yang terdiri dari pasangan himpunan berhingga dari obyek yang disebut titik (vertex) dan pasangan titik yang disebut sisi (edge ).

Definisi 1. Suatu graf $G$ merupakan suatu pasangan himpunan $(V, E)$ dinotasikan dengan $G=(V, E)$, dengan $V$ adalah himpunan berhingga dan tidak kosong dari objek - objek yang disebut titik (vertex) dan E adalah himpunan pasangan tidak terurut dari elemen - elemen $V$ yang berbeda yang disebut sisi (edge).

Salah satu permasalahan di dalam graf yang dapat digunakan untuk menyelesaikan berbagai fenomena di dunia nyata adalah Traveling Salesman Problem (TSP). TSP berkaitan dengan pencarian rute optimal sedemikian sehingga seorang salesman dapat mengunjungi semua tempat tepat satu kali, dimulai dari dan kembali ke tempat asal yang sama.

Permasalahan Bus Traffic Transit merupakan permasalahan yang dapat direpresentasikan sebagai permasalahan TSP. Contoh lain yang berkaitan dengan TSP adalah pencarian rute bis sekolah untuk mengantarkan siswa, pengambilan tagihan telepon, efisiensi pengiriman surat atau barang, perancangan pemasangan pipa saluran dan lain-lain. Persoalan yang muncul adalah bagaimana cara mengunjungi node (simpul) pada graf dari titik awal ke setiap titik titik lainnya dengan bobot minimum (biaya paling murah) dan kembali lagi ke asal node. Bobot atau biaya ini sendiri dapat mewakili berbagai hal, seperti berapa biaya minimum, jarak minimum, bahan bakar minimal, waktu minimum dan lain - lain.

\section{Algoritma Genetika}

\subsection{Istilah dalam Algoritma Genetika}

Algoritma genetika merupakan teknik pencarian heuristic. Istilah-istilah dan parameterparameter yang sering muncul dalam Algoritma Genetika adalah:

- Populasi, merupakan sejumlah kemungkinan solusi dan merupakan kumpulan kromosom.

- Gen, variabel dasar yang membentuk suatu kromosom. Gen dapat bernilai biner, float, integer maupun karakter.

- Kromosom, individu yang terdapat dalam satu populasi dan merupakan gabungan gen gen yang membentuk nilai tertentu. 
Karels, Rheeza Effrains, Jusmawati, Nurdin

- Generasi, populasi awal dibangun secara acak sedangkan populasi selanjutnya merupakan hasil evolusi kromosom-kromosom melalui iterasi dan menyatakan satu siklus proses evolusi atau satu iterasi di dalam algoritma genetika.

- Fungsi Fitness, alat ukur yang digunakan untuk proses evaluasi kromosom. Nilai fitness dari suatu kromosom akan menunjukkan kualitas kromosom dalam populasi tersebut.

- Offspring yang terbentuk dari gabungan dua kromosom induk (parent) yang muncul sebagi akibat dari seleksi, penyilangan (crossover) atau mutasi

\subsection{Operator Algoritma Genetika Sederhana}

Secara garis besar, operator dalam algoritma genetika terdiri dari 3 operator, yaitu:

\section{Seleksi (Reproduksi)}

Operator reproduksi memiliki beberapa metode seleksi diantaranya yaitu roulettewheel, tournament selection dan lain-lain. Dalam masalah kali ini digunakan seleksi dengan metode roulettewheel. Seleksi ini bertujuan untuk memberikan kesempatan reproduksi yang lebih besar bagi anggota populasi yang memiliki fitness tinggi untuk melakukan reproduksi.

\section{Penyilangan (crossover)}

Operator selanjutnya setelah reproduksi yaitu penyilangan (crossover). Penyilangan dilakukan atas 2 kromosom untuk menghasilkan kromosom baru/offspring. Kromosom anak yang terbentuk akan mewarisi sebagian sifat kromosom induknya. Metode crossover yang paling sering digunakan antara lain adalah penyilangan satu titik (one-point crossover), penyilangan banyak titik (multi-point crossover), atau penyilangan dengan Metode Order (OX).

\section{Mutasi}

Operator mutasi akan mengubah nilai dari suatu kromosom pada posisi tertentu berdasarkan peluang mutasi. Peluang mutasi menunjukkan presentasi jumlah total gen pada populasi yang akan mengalami mutasi.

\subsection{Penentuan Parameter}

Parameter kontrol dalam Algoritma Genetika meliputi ukuran populasi (popsize), peluang crossover $\left(\mathrm{p}_{\mathrm{c}}\right)$ dan peluang mutasi $\left(\mathrm{p}_{\mathrm{m}}\right)$. Beberapa nilai yang direkomendasi untuk penentuan parameter diberikan sebagai berikut:

- Untuk permasalahan yang memiliki kawasan solusi cukup besar, De Jong merekomendasikan nilai parameter : (popsize; $\left.\mathrm{p}_{\mathrm{c}} ; \mathrm{p}_{\mathrm{m}}\right)=(50 ; 0,6 ; 0,001)$.

- Bila rata-rata fitness setiap generasi digunakan sebagai indikator, maka Grefenstette merekomendasikan : $\left(\right.$ popsize; $\left.\mathrm{p}_{\mathrm{c}} ; \mathrm{p}_{\mathrm{m}}\right)=(30 ; 0,95 ; 0,01)$.

- Bila fitness dari individu terbaik dipantau pada setiap generasi, maka usulannya : (popsize; $\left.\mathrm{p}_{\mathrm{c}} ; \mathrm{p}_{\mathrm{m}}\right)=(80 ; 0,45 ; 0,01)$.

- Ukuran populasi sebaiknya tidak lebih kecil dari 30, untuk sembarang jenis permasalahan. 
Karels, Rheeza Effrains, Jusmawati, Nurdin

\section{Hasil Dan Pembahasan}

- Sebagaimana telah disebutkan sebelumnya, permasalahan BRT dapat diterjemahkan sebagai sebuah permasalahan graf. Dalam hal ini, sebuah halte digambarkan sebagai sebuah titik graf, sedangkan jalur yang menghubungkan antar halte digambarkan sebagai sebuah sisi graf. Secara lebih khusus, persoalan jalur BRT (Bus Rapid Transit) berkaitan dengan graf terboboti, dimana sisi - sisi graf memiliki bobot yang bersesuaian dengan jarak koordinat antara 2 halte terhubung. Data diperoleh dari penelusuran jalur BRT kota Makassar melalui Google Map sebagaimana diperlihatkan pada Gambar 1 dengan titik koordinat dan jarak antara halte ditampilkan pada Tabel 1. Jarak dari titik ke titik menggunakan perhitungan jarak Euclidean

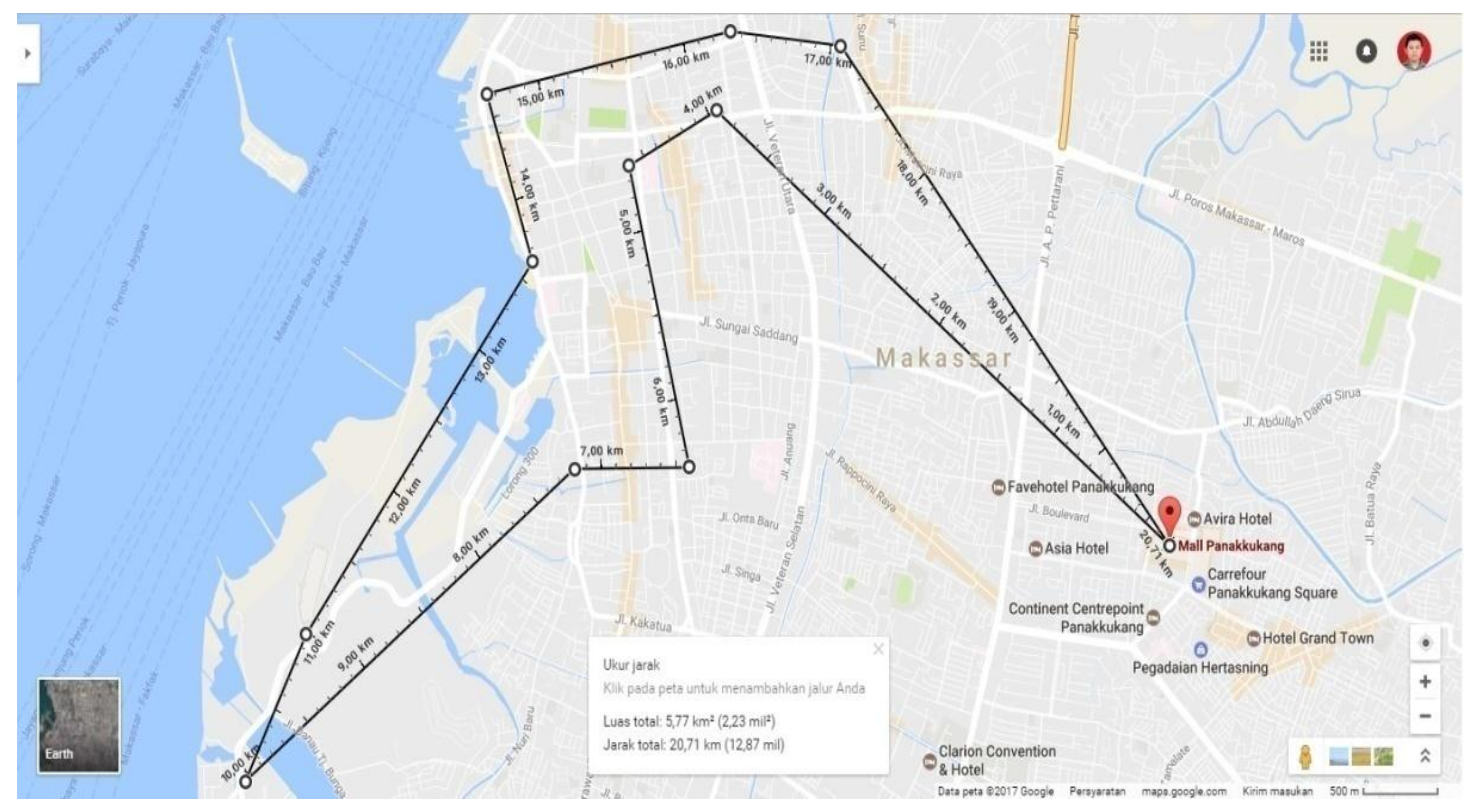

Gambar 1. Peta jalur BRT kota Makassar

Tabel 1. 


\begin{tabular}{|c|c|c|c|c|c|c|c|c|c|c|c|}
\hline & MP & GTC & Anjungan & Trans Mall & Roterdam & M. Raya & M. Almarkas & Mandala & BatalyonZeni & Mari & SMA1 \\
\hline MP & 0 & 6.36 & 4.53 & 5.82 & 5.28 & 4.19 & 3.64 & 4.25 & 4.03 & 3.26 & 3.96 \\
\hline GTC & 6.36 & 0 & 3.57 & 1.04 & 4.3 & 5.43 & 5.84 & 4.4 & 2.86 & 3.49 & 5.01 \\
\hline Anjungan & 4.53 & 3.57 & 0 & 2.54 & 1.04 & 1.89 & 2.42 & 0.861 & 1.21 & 1.58 & 1.52 \\
\hline Trans Mall & 5.82 & 1.04 & 2.54 & 0 & 3.26 & 4.43 & 4.88 & 3.39 & 1.99 & 2.71 & 4.02 \\
\hline Roterdam & 5.28 & 4.3 & 1.04 & 3.26 & 0 & 1.68 & 2.4 & 1.04 & 2.25 & 2.56 & 1.55 \\
\hline M. Raya & 4.19 & 5.43 & 1.89 & 4.43 & 1.68 & 0 & 0.746 & 1.03 & 2.74 & 2.54 & 0.463 \\
\hline M. Almarkas' & 3.64 & 5.84 & 2.42 & 4.88 & 2.4 & 0.746 & 0 & 1.58 & 3.03 & 2.64 & 0.916 \\
\hline Mandala & 4.25 & 4.4 & 0.861 & 3.39 & 1.04 & 1.03 & 1.58 & 0 & 1.8 & 1.8 & 0.669 \\
\hline latalyon Zeni' & 4.03 & 2.86 & 1.21 & 1.99 & 2.25 & 2.74 & 3.03 & 1.8 & 0 & 0.772 & 2.29 \\
\hline Mari & 3.26 & 3.49 & 1.58 & 2.71 & 2.56 & 2.54 & 2.64 & 1.8 & 0.772 & 0 & 2.08 \\
\hline SMA1 & 3.96 & 5.01 & 1.52 & 4.02 & 1.55 & 0.463 & 0.916 & 0.669 & 2.29 & 2.08 & 0 \\
\hline
\end{tabular}

Berdasarkan Gambar 1. maka representasi graf yang bersesuaian memiliki titik sebanyak 11 dan sisi sebanyak 10 .

\subsection{Pengukuran Populasi}

- Nilai obyektif

Setiap individu di dalam populasi menggambarkan sebuah jalur dengan nilai objektifnya berupa total bobot sisi dari graf. Dalam hal ini setiap individu dikodekan ke dalam susunan acak 11 bilangan integer yang menggambarkan urutan jalur-jalur bus dimulai dari titik awal yang tetap dan selanjutnya menuju ke halte yang bersesuaian dengan bilangan berikutnya yang muncul pada kode individu. Nilai objektif dari setiap individu dihitung dengan rumus

$$
D_{i}=\sum_{i, j=1}^{11} C_{i, j}
$$

dengan $\left(C_{i, j}\right)$ merupakan jarak antara dua titik/halte sebagimana diberikan pada Tabel 1 .

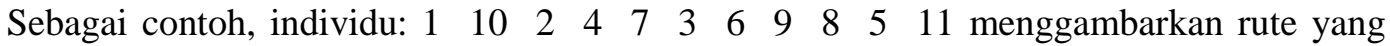
dimulai dari titik awal 1, kemudian berturut-turut ke halte 10, 2,4,7 dan terakhir ke 11 sebelum akhirnya kembali ke titik awal 1. Nilai obyektif untuk individu tersebut adalah 28,07. Nilai obyektif tersebut menyatakan jarak tempuh dengan urutan halte seperti tersebut di atas.

\section{- Nilai Fitness}

Setiap individu memiliki nilai ukuran yang disebut fungsi fitness. Makin besar nilai fitness dari suatu individu, makin besar kemungkinan individu tersebut bertahan sampai generasi berikutnya. Jika permasalahan yang dikaji berkaitan dengan penentuan nilai maksimal, maka fungsi fitness dikonstruksi sebagai fungsi yang berbanding lurus dengan fungsi obyektif. Sebaliknya, jika permasalahan yang dikaji berkaitan dengan penentuan nilai minimal, maka fungsi fitness dikonstruksi sebagai fungsi yang berbanding terbalik dengan fungsi obyektif.

Karena masalah BRT berkaitan dengan persoalan meminimalkan jarak tempuh, maka nilai fitness dikonstruksi dengan menggunakan rumus :

$$
\text { Nilai Fitness }\left(\text { Fit }_{i}\right)=\frac{1}{D_{i}}
$$

Tabel 2. menunjukkan populasi awal berukuran 10 dengan nilai fitness masing-masing. 
Karels, Rheeza Effrains, Jusmawati, Nurdin

Tabel 2 .

\begin{tabular}{|c|c|cccccccccccc|c|}
\hline NO. & \multicolumn{7}{|c|}{ Kromosom } & Fitness \\
\hline 1 & 1 & 2 & 11 & 9 & 7 & 4 & 3 & 8 & 6 & 10 & 5 & 0.02749 \\
2 & 1 & 3 & 7 & 5 & 8 & 9 & 4 & 11 & 10 & 2 & 6 & 0.02992 \\
3 & 1 & 3 & 4 & 11 & 6 & 5 & 7 & 8 & 10 & 9 & 2 & 0.03444 \\
4 & 1 & 10 & 4 & 3 & 2 & 8 & 6 & 5 & 11 & 7 & 9 & 0.03478 \\
5 & 1 & 4 & 10 & 9 & 6 & 7 & 3 & 8 & 2 & 5 & 11 & 0.03299 \\
6 & 1 & 3 & 7 & 8 & 5 & 10 & 11 & 6 & 9 & 4 & 2 & 0.03726 \\
7 & 1 & 7 & 8 & 10 & 5 & 6 & 11 & 4 & 3 & 2 & 9 & 0.03475 \\
8 & 1 & 8 & 3 & 11 & 10 & 7 & 9 & 2 & 4 & 6 & 5 & 0.03366 \\
9 & 1 & 11 & 6 & 8 & 4 & 2 & 3 & 10 & 5 & 9 & 7 & 0.03767 \\
10 & 1 & 10 & 2 & 4 & 7 & 3 & 6 & 9 & 8 & 5 & 11 & 0.03558 \\
\hline
\end{tabular}

Dengan proses seleksi menggunakan metode roulette wheel, crossover menggunakan metode order OX, dan dengan peluang mutasi 0,07 , ukuran populasi 10 serta jumlah generasi 100, maka diperoleh nilai fitness minimum 0,05084. Nilai ini tercapai dari generasi ke 80 sampai generasi sesudahnya. Pengulangan running program menghasilkan nilai minimum yang sama. Individu yang bersesuaian dengan nilai fitness minimum adalah, 1761185423910

dengan urutan jalur sebagaimana diperlihatkan pada Gambar 2. berikut ini:

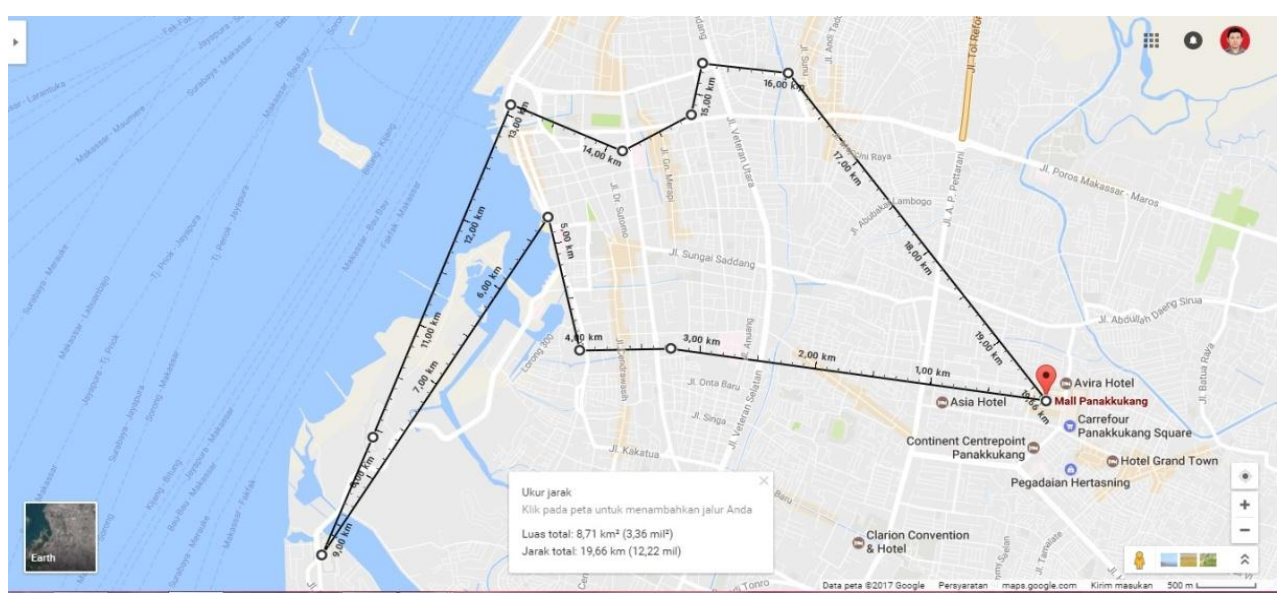

Gambar 2. Jalur BRT dengan total jarak minimum

\section{Kesimpulan}

Permasalahan BRT (Bus Rapid Transit) yang dikaji dalam tulisan ini berkaitan peminimalan total jarak antara halte sekali tempuh hingga kembali ke titik awal keberangkatan. Terminologi jarak yang digunakan dibatasi pada jarak Euclid antara halte dan tidak mempertimbangkan jalur yang dilewati. Dengan menggunakan Algoritma Genetika pada populasi berukuran 10 dengan pengulangan atau generasi sebesar 100, maka nilai optimal diperoleh ketika fungsi fitness bernilai 0,05084, dengan total jarak minimum sebesar $19,66 \mathrm{~km}$ atau setara dengan 12,22 mil. Rute yang ditempuh direpresentasikan oleh kromosom: 1761185423910 dengan rute seperti pada Gambar 2. 
Karels, Rheeza Effrains, Jusmawati, Nurdin

\section{Daftar Pustaka}

[1] Amin, A. R., Ikhsan, M., \& Wibisono, L., 2003. Traveling SalesmanProblem. Institut Teknologi Bandung.

[2] Chartrand, G., \& Zhang, P., 2005. Introduction to Graph Theory. McGraw-Hill, New York

[3] Kumara Sastry, David Goldberg. https://pdfs.semanticscholar.org/ 8ed1/ d9f5a017c61abfec4089aba828b398aa3e7e.pdf (diakses 10 Junli 2019) 